\title{
Removal of organic and nitrogen in a novel anoxic fixed-bed $/$ aerobic fluidized-moving bed integrated with a constructed wetland bio-reactor (A/O-FMCW)
}

\author{
Changmiao Lai ${ }^{1}$, Yu Sun ${ }^{1}$, Yong Guo ${ }^{2}$, Qin $\mathrm{Cai}^{1}$, and Ping Yang ${ }^{1, *}$ \\ ${ }^{1}$ College of Architecture and Environment, Sichuan University, Chengdu, 610065, China \\ ${ }^{2}$ School of Chemical Engineering, Sichuan University, Chengdu, 610065, China
}

\begin{abstract}
An innovative hybrid process was designed using an integrated bio-reactor based on an anoxic / aerobic process that combined a fixed bed and a fluidized-moving bed with a constructed wetland (A/O$\mathrm{FMCW}$ ) to enhance the removal of organic material and nitrogen. The goal was to achieve stringent discharge standards for rural domestic wastewater treatment. A preliminary lab-scale investigation of about 130 days obtained an average COD (Chemical Oxygen Demand) removal rate as high as $92.2 \%$ at an average influent concentration of $319.5 \mathrm{mg} / \mathrm{L}$. The average TN (Total Nitrogen) removal efficiency positively correlated with the attached-growth biofilm as observed by SEM (Scanning Electron Microscope), and declined from 79.1\% to $53.2 \%$. The was accompanied by a gradual increase in the average influent concentration from 16.73 to $52.01 \mathrm{mg} / \mathrm{L}$ despite the relative nitrification rate fluctuating between $92.5 \%$ and $97.9 \%$. The entire integrated system improved the COD removal efficiency by nearly $36 \%$ and the TN by $14-28 \%$. Classical autotrophic nitrification and heterotrophic denitrification were the main mechanisms responsible for the elimination of pollutants, and the latter was determined to be the limiting step. Overall, this study provides an effective and less expensive alternative method to apply or upgrade DWWT (Decentralized Wastewater Treatment).
\end{abstract}

\section{Introduction}

To prevent deterioration of aquatic environments (e.g., eutrophication) due to the rapid urbanization of China, more stringent legislation has been recently enacted that requires increased elimination of organic substances and nitrogen from wastewater $[1,2]$. However, low population density and imperfect public sewer networks in rural areas $[3,4]$ have led to the leakage of untreated wastewater containing nitrogenous compounds. This wastewater directly pollutes both the surface and groundwater, which leads to the need for decentralized wastewater treatment (DWWT).

To develop a sustainable and effective DWWT, low infrastructure investments and operational costs, high flexibility, simple management, low energy consumption, and stable removal capacities are all needed [5]. When looking at mature applications and simple management, conventional nitrification-denitrification technologies like the anoxic-oxic (A/O) process, a classical biological nitrogen removal (BNR) treatment are likely to be more suitable for rural areas $[2,6]$. Nitrate recycling in an aerobic unit occurs when ammonium $\left(\mathrm{NH}_{4}{ }^{+}-\mathrm{N}\right)$ is converted into nitrates $\left(\mathrm{NO}_{3}^{-}-\mathrm{N}\right)$ by ammonium oxidizing bacteria $(\mathrm{AOB})$ or nitrification by nitrite oxidizing bacteria (NOB). Denitrifying bacteria (DB) or heterotrophic bacteria (HB) oxidize carbon using nitrate as an electron acceptor during anaerobic respiration and remove both organic compounds and nitrogen from wastewater.
To date, biofilm systems, like fluidized bed reactors (FBRs) [7], and moving bed reactors (MBRs) [8], can purify most organic pollutants, nutrients, as well as partially toxic substances [9]. Advantages, such as the high specific surface area of biofilm carriers/medias, no need for sludge recycling or longer sludge retention times (SRT), flexibility and low-cost operation make biofilm technologies popular candidates to solve decentralized domestic sewage treatment problems. The coexistence of aerobic and anoxic metabolic activities in the same biomass ecosystem for simultaneous nitrification and denitrification (SND) also make biofilm technologies attractive [10]. Meanwhile, constructed wetlands (CWs) are also considered a promising water purification technology for treated sewage effluents since they have a low-energy consumption, are environmentally friendly, and have low construction and operation costs [11]. Wetland sediments provide suitable habitats for microbial communities that are associated with the biogeochemical nitrogen removal cycle. Autotrophic nitrification and heterotrophic denitrification occur in CWs under microscale redox gradients for nitrogen removal $[12,13]$.

Therefore, some lab- or pilot- scale devices that integrate a series of process units, especially ecological processes, have gradually gained attention. For instance, the vegetation-activated sludge process (V-ASP) [4], Green Bio-sorption Reactor (GBR) [14], the waterman farm ecological treatment system (WETS) [15], and

* Corresponding author: yangpinga301@163.com 
integrated $\mathrm{A} / \mathrm{O}$ reactors [2], have been developed and have shown consistently higher organic material and nutrient pollutant removal efficiencies. There are interesting trends that environmentally-friendly, stable and stringent effluent quality all required in DWWT, which has led to the development of hybrid processes to improve future applications.

Current studies, however, have primarily focused on upgrading wastewater treatment processes in wastewater treatment plants (WWTPs) near urban areas for enhanced removal, reduced energy consumption, and better aesthetic value [14]. However, only a few studies have reported DWWTs. As described before, the use of a single technology cannot meet all requirements, and hybrid processes are needed for future DWWTs.

Herein, an innovative hybrid process is designed in the form of an integrated bio-reactor based on an anoxic/aerobic process that combines a fixed bed and fluidized-moving bed with a constructed wetland, named A/O-FMCW. Here, "A/O" refers to the classical anoxic/oxic process, " $F$ " and " $M$ " represent fixed-bed and fluidized-moving bed respectively, and " $\mathrm{CW}$ " stands for constructed wetland. The aim of this paper is thus to evaluate the feasibility and efficiency and to illuminate the mechanism of the A/O-FMCW when it is used to remove organic material and nitrogen from synthetic domestic wastewater. The results in this study can be used to guide future DWWT applications.

\section{Material and methods}

\subsection{Reactor configuration}

A novel plexiglass-made cuboid integrated bio-reactor with $50 \mathrm{~cm}$ length, $20 \mathrm{~cm}$ width, and $55 \mathrm{~cm}$ height with a total working volume of $46.8 \mathrm{~L}$ was fabricated and used in the present research.

Based on a conventional A/O process, a bio-reactor was separated into an anoxic $(8.5 \mathrm{~L})$, oxic $(25.5 \mathrm{~L})$, sediment $(8.0 \mathrm{~L})$, and wetland zones $(4.8 \mathrm{~L})$ which each differed in their function and location. The wetland zone was located atop the $\mathrm{A} / \mathrm{O}$-zones, separated by a piece of a plexiglassmade plate with a waterproof treatment on its edge. The hydroponic plant in the wetland created landscapes and prevented odors.

The fluidized movement of mixed bio-carriers in the oxic-zone occurred via the aeration from the air pipe at the bottom, and the strength was adjusted by a flowmeter with a flow rate of $400 \mathrm{~L} / \mathrm{h}$. The influent flow and internal recycle were both controlled by peristaltic pumps, and the schematic of the A/O-FMCW is shown in Figure 1.

\subsection{Bio-carriers and plants}

A total of five bio-carriers or substrates were used in the bio-reactor to provide a large surface for microbial attachment.

Flexible fiber, with a specific packing rate of $30 \mathrm{~m}^{2} / \mathrm{m}^{3}$, was supported by inner brackets in the fixed-bed carriers in the anoxic zone. A porous polymer carrier [16], labeled PPC and a cylindrical polypropylene carrier [17], labeled
CPC, were added into the oxic-zone with volumetric packing rates of $5 \%$ and $15 \%$, respectively. Their specific surface areas were $5357 \mathrm{~m}^{2} / \mathrm{m}^{3}$ and $1200 \mathrm{~m}^{2} / \mathrm{m}^{3}$, respectively. The total packing rate of bio-carriers in the aerobic unit was set as $20 \%$, which was demonstrated to be the suitable packing rate in an MBBR system [18].

A complete wetland configuration was used in the bioreactor, including substrates and plants. Quartzite and gravel were used as the wetland substrate, the microbial attachment, and for plant fixation and root growth. A 10 $\mathrm{cm}$-thick gravel layer was placed under a $2 \mathrm{~cm}$-thick quartzite layer. The species of plants were Anthurium andraeanum Linden, Spathiphyllum kochii Engl. et Krause, Aglaonema commulatum, and Dieffenbachia sequina (Linn.) Schott, respectively.

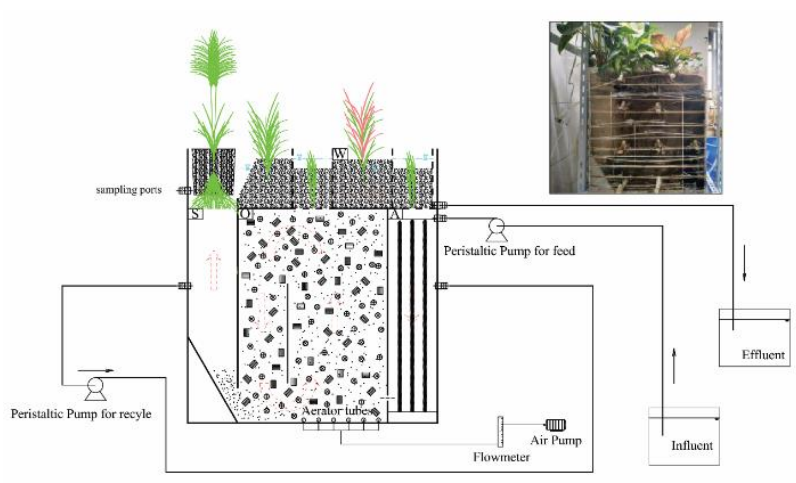

Fig. 1. Schematic diagram of the A/O-FMCW.

\subsection{Synthetic wastewater and start-up period}

The reactor was fed by synthetic wastewater whose composition and concentration simulated domestic sewage of rural areas [19], consisting of $0.3 \mathrm{~g} / \mathrm{L} \mathrm{C}_{6} \mathrm{H}_{12} \mathrm{O}_{6}$ (glucose), $0.015 \mathrm{~g} / \mathrm{L} \mathrm{KH}_{2} \mathrm{PO}_{4}, 1 \mathrm{~g} / \mathrm{L} \mathrm{NaHCO}_{3}$, and $0.05 \mathrm{~g} / \mathrm{L}, 0.075 \mathrm{~g} / \mathrm{L}$, $0.1 \mathrm{~g} / \mathrm{L}, 0.15 \mathrm{~g} / \mathrm{L}$, and $0.19 \mathrm{~g} / \mathrm{L}$ of $\mathrm{NH}_{4} \mathrm{Cl}$ in different stages, respectively. Micronutrients were added to the influent 1 $\mathrm{ml} / \mathrm{L}$ at the same time, including $0.15 \mathrm{~g} / \mathrm{L} \mathrm{H}_{3} \mathrm{BO}_{3}, 5 \mathrm{~g} / \mathrm{L}$ $\mathrm{MgSO}_{4} \cdot 7 \mathrm{H}_{2} \mathrm{O}, 0.3 \mathrm{~g} / \mathrm{L} \mathrm{FeSO}_{4} \cdot 7 \mathrm{H}_{2} \mathrm{O}, 0.4 \mathrm{~g} / \mathrm{L} \mathrm{ZnSO}_{4} \cdot 7 \mathrm{H}_{2} \mathrm{O}$, $0.2 \mathrm{~g} / \mathrm{L} \mathrm{MnCl}_{2} \cdot 4 \mathrm{H}_{2} \mathrm{O}, 0.1 \mathrm{~g} / \mathrm{L} \mathrm{CaCl}_{2}, 0.45 \mathrm{~g} / \mathrm{L} \mathrm{CoSO}_{4} \cdot 7 \mathrm{H}_{2} \mathrm{O}$, $0.25 \mathrm{~g} / \mathrm{L} \mathrm{NiCl} \cdot 6 \mathrm{H}_{2} \mathrm{O}$, and $0.05 \mathrm{~g} / \mathrm{L} \mathrm{CuCl}_{2} \cdot 2 \mathrm{H}_{2} \mathrm{O}$. All compounds were of analytical grade or higher $(>99 \%$ purity).

The purpose of the start-up period was to aggregate the biomass and form a biofilm on the bio-carriers. Ten liters of the seed sludge containing $1300 \mathrm{mg} \mathrm{VSS} / \mathrm{L}$ (from Huayang WWTP, Chengdu, China), was used for the inoculation. After about 20 days of continuous inflow, and with the hydraulic retention time (HRT) and aeration flow set to $11.7 \mathrm{~h}$ and $400 \mathrm{~L} / \mathrm{h}$, respectively, attached biofilms were visible on carrier materials.

\subsection{Operation strategy}

Experiments were performed consecutively for five months. There were ten stages in total that were classified in two phases (labeled A and B, respectively), which were studied to explore the nitrogen removal capacity potential of bio-reactors, as well as removal of organic material. 
The purpose of phase A was to explore the A/O process general treatment capacity under five different chemical oxygen demand/total nitrogen $(\mathrm{C} / \mathrm{N})$ ratios, which were realized by increasing the $\mathrm{NH}_{4}{ }^{+}-\mathrm{N}$ influent loading. The purpose of phase $\mathrm{B}$ was to evaluate whether there was a further optimization effect of the treatment when used in a wetland system.

Aside from the nitrogen influent loadings, other operation parameters, such as temperature $\left({ }^{\circ} \mathrm{C}\right), \mathrm{pH}, \mathrm{DO}$, organic loadings, TP loadings, and recycling ratio, were kept constant. Each stage lasted for around 13 days. A comprehensive summary of the experimental conditions is given in Table 1.

\subsection{Analytical methods}

Samples were collected every two or three days from influent, effluent, and sediment zones, and immediately analyzed. $\mathrm{COD}, \mathrm{NH}_{4}{ }^{+}-\mathrm{N}, \mathrm{NO}_{2}^{-}-\mathrm{N}, \mathrm{NO}_{3}^{-}-\mathrm{N}, \mathrm{TN}, \mathrm{MLSS}$ and MLVSS were determined according to standard methods [20]. Moreover, a scanning electron microscope (SEM, S520, Hitachi Co., Japan) was used to observe the morphology of attached-growth biomass.

Table 1. Phase classification and operational conditions of the whole experiment

\begin{tabular}{|c|c|c|c|c|c|c|}
\hline \multirow{2}{*}{ Stage } & \multirow{2}{*}{ Day } & \multicolumn{3}{|c|}{ Average influent concentration $(\mathrm{mg} / \mathrm{L})$} & \multirow{2}{*}{$\mathrm{C} / \mathrm{N}$} & \multirow{2}{*}{ Other conditions } \\
\hline & & $\mathrm{NH}_{4}^{+}-\mathrm{N}$ & TN & COD & & \\
\hline A-1 & $1-13$ & $13.00 \pm 0.19$ & $14.89 \pm 0.46$ & $310 \pm 8$ & $17.5 \pm 2.3$ & \multirow{10}{*}{$\begin{array}{l}\text { 1) Alkalinity source: } \mathrm{NaHCO}_{3}(1 \mathrm{~g} / \mathrm{L}) \\
\text { 2) Inflow rate: } 86.4 \mathrm{~L} / \mathrm{d} \\
\text { 3) Recycling ratio: } 3: 1 \\
\text { 4) } \mathrm{DO} \text { in A-zone and O-zone were controlled as } \\
0.26-0.63 \text { and } 3.02-4.34 \text {, respectively. } \\
\text { 5) } \mathrm{pH} \text { in A-zone and O-zone were detected as } \\
7.36-7.93 \text { and } 8.03-8.44 \text {, respectively. }\end{array}$} \\
\hline A-2 & $14-26$ & $21.13 \pm 1.32$ & $22.33 \pm 0.90$ & $310 \pm 11$ & $10.0 \pm 1.0$ & \\
\hline A-3 & $27-39$ & $27.17 \pm 1.26$ & $28.86 \pm 1.11$ & $310 \pm 11$ & $7.5 \pm 0.3$ & \\
\hline A-4 & $40-52$ & $39.34 \pm 0.21$ & $41.24 \pm 0.55$ & $304 \pm 10$ & $4.5 \pm 0.4$ & \\
\hline A-5 & $53-65$ & $50.20 \pm 0.91$ & $52.76 \pm 0.83$ & $314 \pm 8$ & $3.2 \pm 0.2$ & \\
\hline B-1 & $66-78$ & $13.76 \pm 0.68$ & $16.73 \pm 1.48$ & $313 \pm 7$ & $14.6 \pm 2.3$ & \\
\hline B-2 & $79-91$ & $19.59 \pm 0.96$ & $22.17 \pm 0.53$ & $315 \pm 3$ & $10.5 \pm 0.4$ & \\
\hline B-3 & $92-104$ & $26.53 \pm 0.65$ & $29.10 \pm 0.91$ & $310 \pm 8$ & $6.7 \pm 0.6$ & \\
\hline B-4 & $105-117$ & $40.57 \pm 1.17$ & $42.57 \pm 1.27$ & $325 \pm 14$ & $4.6 \pm 0.3$ & \\
\hline B-5 & $118-129$ & $49.78 \pm 0.84$ & $52.01 \pm 0.90$ & $318 \pm 6$ & $3.4 \pm 0.1$ & \\
\hline
\end{tabular}

a. Phase A used the bio-reactor without the wetland configuration.

b. Phase B used the bio-reactor with the wetland configuration.

c. $\mathrm{C} / \mathrm{N}=$ influent concentration of $\mathrm{COD} /$ influent concentration of $\mathrm{TN}$ after dilution

d. PPC bio-carriers returned to O-zone artificially in stage B-3 because of their accumulation in sediment bottom

\section{Results and discussion}

\subsection{Biomass characteristics}

Biomass was present in mainly two forms in the bio-reactor: attached or suspended [21]. The elimination of organic material or nitrogen in the reactor was mainly accomplished by the biochemical process taking place via suspended sludge and attached growth biofilms. The biomass concentration variation is illustrated in Figure 2. The attached-growth biofilm was clearly the dominant among the total biomass, with an average proportion up to $82.5 \%$ in phase $\mathrm{A}$ and $83.7 \%$ in phase $\mathrm{B}$. The total biomass amounts in phase B ranged from 3.73 to $4.12 \mathrm{~g} / \mathrm{L}$, which was higher than that of phase $\mathrm{A}$ which ranged from 3.54 to $3.86 \mathrm{~g} / \mathrm{L}$. Further comparing CPC and PPC, the AGB of PPC was as high as $2.48-3.07 \mathrm{~g} / \mathrm{L}$, almost 7-9 times the concentration of CPC, which ranged from $0.30-0.45 \mathrm{~g} / \mathrm{L}$. The most reasonable explanation is that the different sizes of the bio-carriers affected their hydrodynamics properties such as shear force and flow regime in the bulk liquid, which sequentially influenced the biomass aggregation and distribution. Microorganisms preferably grew in the spacings provided by particle irregularities, which protected them from shear forces of the bulk liquid. PPC has an approximately spherical shape smaller than $1 \mathrm{~mm}$, and has interior spacings and a rough exterior. These characteristics are useful for biomass attachment, but make

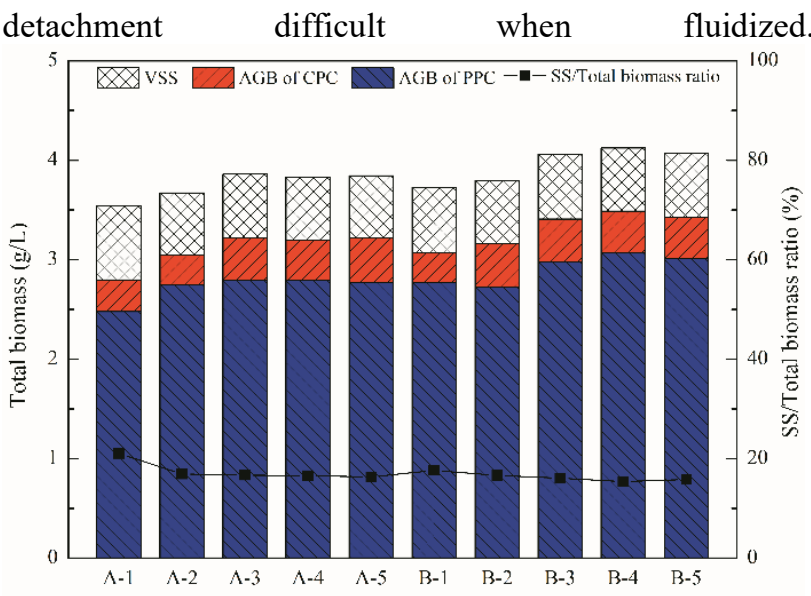

Fig. 2. Variation of biomass fraction in $\mathrm{O}-\mathrm{zone}$ of $\mathrm{A} / \mathrm{O}-\mathrm{FMCW}$.

In general, microbial aggregation led to the formation of biofilms, which mainly depended on substrate loading rate and shear force. In this work, the quantity of AGB increased slowly during the first four stages of each phase along with the nitrogen loading under $0.083 \mathrm{~g} /(\mathrm{L} \cdot \mathrm{d})$. When the nitrogen loading continued to increase to $0.106 \mathrm{~g} /(\mathrm{L} \cdot \mathrm{d})$, the AGB decreased because the outer biofilm growth layer detached due to the shear forces generated by the airflow controlled at $400 \mathrm{~L} / \mathrm{h}$, or by collisions among bio-carriers within the mixed bulk liquid. Based on these assumptions, the thickness of attached-growth biofilms was present in a maximum value in the reactor under certain conditions, which led to a relatively stable concentration of attachedgrowth biomass. 
The SEM images of bio-carriers with or without attached biomass shown in Figure 3. The PPC has a relatively rough surface and a porous structure (Fig.3a), while CPC has a relatively smooth surface (Fig. 3b). After sludge inoculation and operation for about 20 days, microorganisms clearly began to grow on the surface of PPC and CPC, as shown in Fig. 3c and d. Biofilms were tightly integrated with others and small internal spaces were present. Judging from the morphology of the biomass, filamentous or rob-shaped microbes dominated the surface of CPC, while cocci or tadpole-shaped microbes dominated the surface of PPC. The different dominant microorganism species were likely linked to the differences between CPC and PPC as bio-carriers such as their structures, materials, shape and size, fluidization state in the reactor, and functional divisions during organic biodegradation and nitrification. According to the SEM images, stable attachment of biomass, as well as a superior diversity of microbial species on the separate bio-carriers, were obtained in the oxic-zone. This indicated an expectable removal capacity of organic and nitrogen pollutants.

\subsection{Overall removal performance}

The overall removal performance is shown in Figure 4. The average COD influent concentration fluctuated from 285 to $331 \mathrm{mg} / \mathrm{L}$ in phase $\mathrm{A}$, and from 299 to $343 \mathrm{mg} / \mathrm{L}$ in phase B. After the $\mathrm{A} / \mathrm{O}$ process, the effluent concentration decreased to $38 \pm 12 \mathrm{mg} / \mathrm{L}$ with an average COD reduction of $87.6 \%$ in phase $\mathrm{A}$ and to $25 \pm 7 \mathrm{mg} / \mathrm{L}$ with an average COD reduction of $92.2 \%$ in phase $B$. These results indicated the excellent organic substrate removal capacity of the fluidized-moving bed reactor through the $\mathrm{A} / \mathrm{O}$ process. In addition, the introduction of the wetland process at the end could reduce the COD concentration and effluent fluctuation.

The $\mathrm{NH}_{4}{ }^{+}-\mathrm{N}$ influent concentration and $\mathrm{TN}$ were gradually increased during each stage of phase A and B to explore the potential nitrogen removal capacity of the system. The results showed that the removal efficiency had a negative correlation with the influent concentration of nitrogen compounds. In phase $\mathrm{A}$, the average removal efficiency of $\mathrm{NH}_{4}^{+}-\mathrm{N}$ was $95.7 \%$ with influent of $13.00 \pm 0.19 \mathrm{mg} / \mathrm{L}, 95.2 \%$ with influent of $21.13 \pm 1.32 \mathrm{mg} / \mathrm{L}$, $94.5 \%$ with influent of $27.17 \pm 1.26 \mathrm{mg} / \mathrm{L}, 88.4 \%$ with influent of $39.34 \pm 0.21 \mathrm{mg} / \mathrm{L}, 83.5 \%$ with influent of $50.20 \pm 0.91 \mathrm{mg} / \mathrm{L}$. In addition to the TN removal efficiency during phase $\mathrm{A}$, a decreasing trend was obtained as $82.4 \%$, $75.1 \%, 62.6 \%, 52.0 \%$, and $49.8 \%$. During phase B, the average removal efficiencies were calculated as $95.3 \%$, $92.5 \%, 97.9 \%, 96.9 \%$, and $93.8 \%$ for $\mathrm{NH}_{4}{ }^{+}-\mathrm{N}$ and $79.1 \%$, $73.8 \%, 64.1 \%, 57.8 \%$, and $53.2 \%$ for TN.

From the perspective of discharge standards, a stricter discharge standard (DB51/2311-2016, Sichuan Provincial Department of Environmental Protection, China) has already been implemented, and $\mathrm{COD}, \mathrm{NH}_{4}{ }^{+}-\mathrm{N}$, and $\mathrm{TN}$ are legally required to be $30 \mathrm{mg} / \mathrm{L}, 1.5 \mathrm{mg} / \mathrm{L}$, and $10 \mathrm{mg} / \mathrm{L}$, respectively. Measurement of the effluent during the entire experiment showed that the concentration of phase B was significantly lower than that of phase A. This demonstrated that the removal capacity was enhanced by the integration of a constructed wetland. The average COD effluent was reduced by nearly $36 \%$ from 38 to $25 \mathrm{mg} / \mathrm{L}$ and achieved stricter discharge stability. Regarding TN, the average effluent of phase B was reduced by nearly $28 \%, 14 \%, 25 \%$, $28 \%$, and $21 \%$ to $1.88 \mathrm{mg} / \mathrm{L}, 4.74 \mathrm{mg} / \mathrm{L}, 8.13 \mathrm{mg} / \mathrm{L}, 14.27$ $\mathrm{mg} / \mathrm{L}$, and $20.78 \mathrm{mg} / \mathrm{L}$ under different nitrogen loadings, respectively.

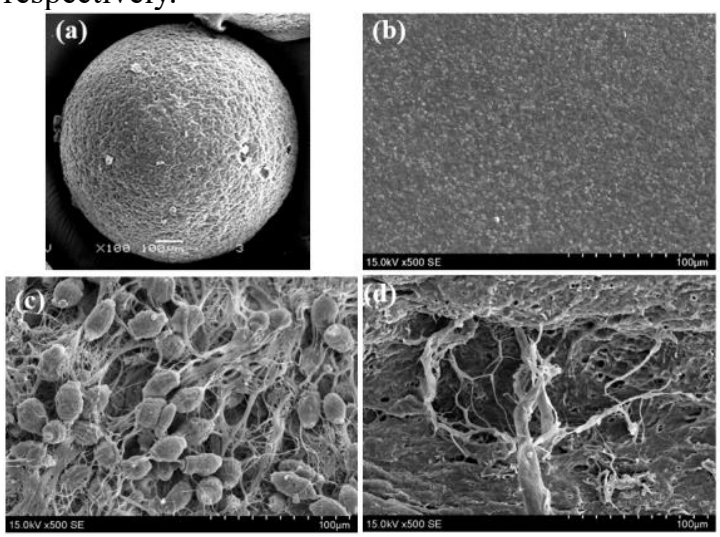

Fig. 3. SEM images of bio-carriers in A/O-FMCW. a) and c), original 500x detailed biomass attachment state of PPC, respectively. b) and d), original, 500x detailed biomass attachment state of CPC, respectively.

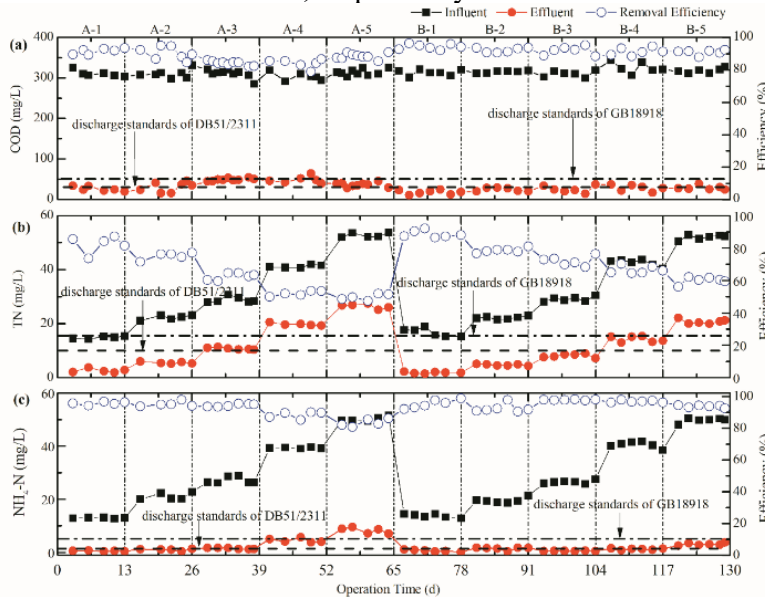

Fig. 4. Overall performance of organics and nitrogen removal. a), COD. b), TN. c), $\mathrm{NH}_{4}^{+}-\mathrm{N}$.

Theoretically, the longer HRT, the higher removal performance in biological system, however, a reasonable HRT is required when considering wastewater type and effluent criteria, as well as construction investment and operational cost. Compared with other processes, like VASPs with HRT of $15 \mathrm{~h}$ [4], IETS with HRT of 28d [22], the A/O-FMCW bioreactor was demonstrated to run continuously and reliably and obtained current sufficient discharge standard of GB18918-2002 in China with a shorter HRT of $11.7 \mathrm{~h}$. Furthermore, the system showed the expected potential to meet the latest stricter standards if the influent nitrogen loading is under $0.0823 \mathrm{~g} /(\mathrm{L} \cdot \mathrm{d})$.

\subsection{Major nitrogen removal through A/O process}

Generally, the removal capacity of the A/O process is closely related to the amount of biomass. As depicted in Figure 5a, there was a small positive correlation between AGB and nitrogen removal quantity as expected. On the 
other hand, the amount of TN removed, which represents the denitrification potential of the bio-reactor, correlated positively with the $\mathrm{C} / \mathrm{N}$ ratio $[23,24]$. The nitrification rate kept above $83.5 \%$ and when $\mathrm{NO}_{3}{ }^{-} \mathrm{N}$ dominated the composition of the effluent, the influent presented a low $\mathrm{C} / \mathrm{N}$ ratio which reduce the effectiveness of the denitrification step [25]. Judging from Figure $5 \mathrm{~b}$, the maximum TN removal was $87 \%$ at a $\mathrm{C} / \mathrm{N}$ ratio of 18 . Provided the $\mathrm{C} / \mathrm{N}$ ratio is above 9 , extrapolation of the nonliner fitting curves of phase A and $\mathrm{B}\left(\mathrm{R}^{2}=0.9240,0.9982\right.$, respectively) showed that the $\mathrm{A} / \mathrm{O}$ process of the bioreactor maintained a $\mathrm{TN}$ removal efficiency around $70 \%$. This is acceptable for DWWT in China, and further elimination can be handled by a constructed wetland. These experimental results are in good agreement with other studies which reported a $\mathrm{C} / \mathrm{N}$ ratio of 12.5 with a $\mathrm{TN}$ removal of $87 \%$ through SBBR [26], $\mathrm{C} / \mathrm{N}$ ratio in the range 9-12 with TN removals between $82-90 \%$ in an SBR system [27], and a $\mathrm{C} / \mathrm{N}$ ratio of 8 with a denitrification efficiency of $72 \%$ [28].

Figure 6 illustrates the bio-reactor's nitrogen removal mechanism. Generally, pre-anoxic conditions are required for denitrification and TN removal. Since the nitrate recycling stream dilutes the influent, an abundance of $\mathrm{NO}_{3}{ }^{-}$ -N and carbon sources, which act as electron acceptors and donors, respectively, accomplish denitrification through the exhaustion of carbon sources by heterotrophic bacteria (HB) or denitrifying bacteria (DB), such as Paracoccus denitrificans. Similarly, post-aerobic nitrification conditions were a key factor for the removal of $\mathrm{NH}_{4}{ }^{+}-\mathrm{N}$. Under aerobic conditions, ammonium oxidizing bacteria (AOB), such as Nitrosomonas, and nitrite oxidizing bacteria (NOB), like Nitrobacter, used dissolved oxygen as an electron acceptor to oxidize $\mathrm{NH}_{4}{ }^{+}-\mathrm{N}$ to $\mathrm{NO}_{2}^{-}-\mathrm{N}$ and $\mathrm{NO}_{3}{ }^{-}-\mathrm{N}$
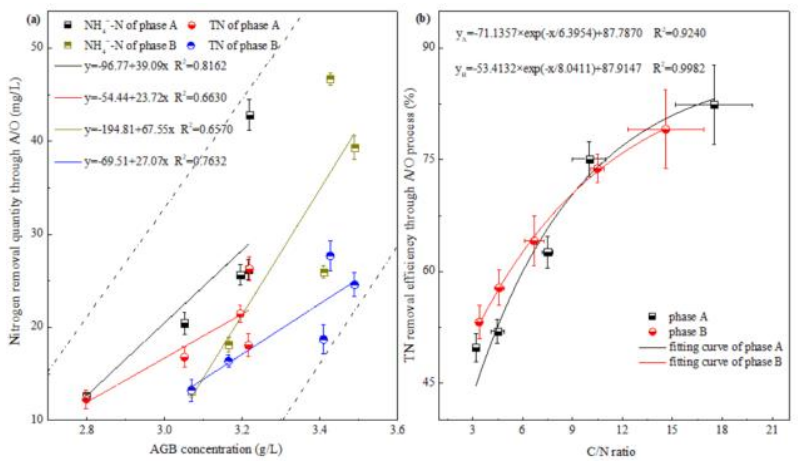

Fig. 5. Experimental results. a), profile relationship between AGB and nitrogen removal quantity. $b$ ), removal variations of $\mathrm{TN}$ with different $\mathrm{C} / \mathrm{N}$ ratios.
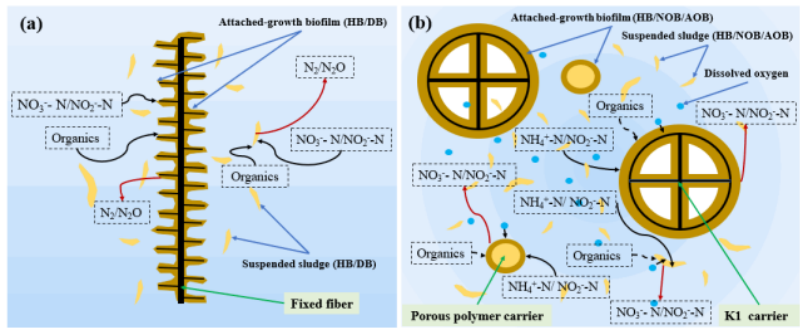

Fig. 6. Proposed mechanistic diagrams of a) denitrification and b) nitrification within the $\mathrm{A} / \mathrm{O}-\mathrm{FMCW}$.

\subsection{Enhanced nitrogen removal through CW}

As pictured in Figure 7, further removal of organic and nitrogen was achieved when water flowed through wetland. The variation of $\mathrm{NH}_{4}^{+}-\mathrm{N}$ and $\mathrm{TN}$ indicated that nitrification and denitrification were simultaneously occurring in the wetland, and it is speculated that denitrification was the main process ongoing, microorganisms attached to the quartzite or gravel surface and consumed carbon and nitrogen.

Autotrophic nitrification and heterotrophic denitrification were accomplished through the microbial activity and acted as important $\mathrm{N}$ turnover processes to remove nitrogen from the wastewater $[15,29]$. In addition, aquatic plants have been shown to have positive effects on the spatial distribution of microbial communities and influence the removal capacity of wetlands [30]. On one hand, oxygen can be delivered to plant roots to oxygenate near the rhizosphere to stimulate microbial nitrification. On the other hand, the growth of roots may reduce the wetland sediment voidage, which in turns cause clogging problems which change the hydraulic path and restric microorganism functions for nitrogen removal.

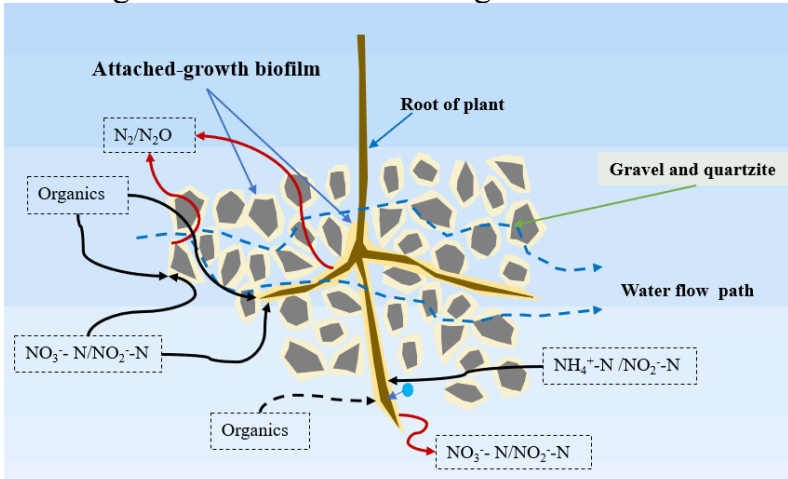

Fig. 7. Proposed removal mechanism in constructed wetland

\subsection{Proposed practical application}

The A/O-FMCW bio-reactor designed in this study was easily designed and rebuilt using a common SBR or MBBR by: a) adding a vertical clapboard to separate the tank into anoxic and aerobic units; b) adding a horizontal clapboard to create a wetland unit above the anoxic and aerobic units, which needed a waterproof treatment and a reserved air plot; and c) choosing and adding suitable and economic bio-carriers and plants into the system. To better simulate a real DWWT that has stricter discharge standards, the novel bio-reactor has the following advantages:

a) An integrated configuration minimized the floor area of treatment facilities using an up-down structure, and this smaller footprint would greatly reduce upfront investment costs. In addition, the wetlands on the top would improve the treatment plant or facilities landscapes by combining ecological and cultural characteristics with local plants, which is preferable in rural areas.

b) The variety of bio-carriers used in the system could potentially increase the biomass and enhance solid retention in a reactor. The aggregate and biofilm formation on bio-carrier surfaces reduced sludge washout, causing an increase in sludge retention time (SRT). Furthermore, wetland filtration could trap suspended solids, which 
would also improve the effluent quality.

c) The fluidization in the oxic-zone enhanced the mass transfer in the reactor, which contributed to substrate permeation (e.g., oxygen, carbon, and nitrogen sources) into the AGB interior to improve microorganism metabolism [31]. Additionally, biofilm thicknesses were efficiently controlled by inner flow shear forces, which stabilized system's capability for pollutants removal.

d) It is likely that the treatment capacity could be further enhanced if modified functional substrates, such as pyrite [32], or plants with better decontamination abilities, like Myriophyllum elatinoides [30], were used in the CWs.

e) To achieve a sustainable use of a DWWT, it must be easily operated with a lower energy consumption. The bioreactor presented here used natural gravity inlets and outlets without requiring additional energy, except for aeration and recycling. The whole system has a simple automatic operation compared to SBR and other techniques.

As this study has shown, the novel system can easily remove $\mathrm{COD}, \mathrm{NH}_{4}{ }^{+}-\mathrm{N}$, and $\mathrm{TN}$. Considering the domestic wastewater characteristics in rural areas of China, the A/OFMCW bio-reactor can meet the most recent effluent standards, avoid odor problems, create plant landscapes, and provide a promising route to upgrade a DWWT.

\section{Conclusion}

The organic and nitrogen removal performances of a novel A/O-FMCW bio-reactor were examined. While the study was only a lab-scale trial, the results demonstrated the current discharge standard stably and continuously had average removal rates of COD, $\mathrm{NH}_{4}{ }^{+}-\mathrm{N}$, and TN of $92.2 \%$, $92.5-97.9 \%$, and $53.2-79.1 \%$, respectively. It also showed an attractive possibility to meet stricter requirements. Autotrophic nitrification and heterotrophic denitrification were the main mechanisms responsible for eliminating pollutants, and the latter was determined to be the limiting step. Additionally, the removal quantity positively affected the attached-growth of biofilms. The A/O-FMCW bioreactor provided an effective and less expensive alternative for DWWT upgrades.

This study was supported by Grants from the township sewage treatment technology integration and demonstration project [grant number 2017SZ0180] of Sichuan Provincial Bureau of Environmental Protection.

\section{References}

1. Q. Feng, Y. Wang, T. Wang, H. Zheng, L. Chu, C. Zhang, H. Chen, X. Kong, XH. Xing. Bioresour. Technol. 117, 201-207 (2012)

2. L. Gong, L. Jun, Q. Yang, S. Wang, B. Ma, Y. Peng. Bioresour. Technol. 119, 277-284 (2012)

3. P. Gu, RF. Shen, YD. Chen. Environ. Sci. Pollut. Res. 15, 273 (2008)

4. J. Yuan, W. Dong, F. Sun, P. Li, K. Zhao. Environ. Sci. Pollut. Res. 23, 10234-10246 (2016)
5. H. Chen, Y. Liu, BJ. Ni, Q. Wang, D. Wang, C. Zhang, X. Li, G. Zeng. Biochem. Eng. J. 113, 114-122 (2016)

6. S. Luostarinen, S. Luste, L. Valentin, J. Rintala. Water Res. 40, 1607-1615 (2006)

7. W. Xing, HH. Ngo, WS. Guo, A. Listowski, P. Cullum. Bioresour. Technol. 102, 5448-5453 (2011)

8. Z. Song, X. Zhang, HH. Ngo, W. Guo, P. Song, Y. Zhang, H. Wen, J. Guo. J. Sci. Total Environ. 651, 1078-1086 (2019)

9. K. Biswas, MW. Taylor, SJ. Turner. Appl. Microbiol Biotechnol. 98, 1429-1440 (2014)

10. H. Dulkadiroglu, EU. Cokgor, N. Artan, D. Orhon. Water Sci. Technol. 51, 95-103 (2005)

11. W. Lan, J. Zhang, Z. Hu, M. Ji, J. Zhang, F. Li, G. Yao. Chem. Eng. J. 335, 209-214 (2018)

12. T. Ligi, M. Truu, K. Oopkaup, H. Nõlvak, Ü. Mander, WJ. Mitsch, J. Truu. Ecol. Eng. 80, 181-190 (2015)

13. M. Zhang, P. Luo, F. Liu, H. Li, S. Zhang, R. Xiao, L. Yin, J. Zhou, J. Wu. Ecol. Eng. 104, 30-38 (2017)

14. Y. Zhao, R. Liu, J. Zhao, L. Xu, C. Sibille. Bioresour. Technol. 234, 224-232 (2017)

15. JA. Morgan, JF. Martin. Ecol. Eng. 33, 195-209 (2008)

16. J. Huang, P. Yang, Y. Guo, K. Zhang. Desalination. 276, 373-378 (2011)

17. X. Liu, L. Wang, L. Pang. Bioresour. Technol. 269, 113-120 (2018)

18. X. Zhang, Z. Song, W. Guo, Y. Lu, L. Qi, H. Wen, HH Ngo. Bioresour. Technol. 245, 1282-1285 (2017)

19. Y. Zhang, Y. Cheng, C. Yang, W. Luo, G. Zeng, L. Lu. Bioresour. Technol. 193, 424-432 (2015)

20. SEPA. Standard methods for the examination of water and wastewater (Environmental Science Press, Beijing, China, 2002)

21. J. Podedworna, M. Zubrowska-Sudol, A. GrabińskaŁoniewska. Water Sci. Technol. 60, 2781-2789 (2009)

22. H. Li, F. Liu, P. Luo, G. Xie, R. Xiao, W. Hu, J. Peng, J. Wu. Eco. Eng. 124, 69-76 (2018)

23. X. Fan, HQ. Li, P. Yang, B. Lai. Desalin. Water Treat. 54, 573-580 (2015)

24. L. Pelaz, A. Gómez, A. Letona, G. Garralón, M. FdzPolanco. Chemosphere. 212, 8-14 (2018)

25. Y. Yang, G. Lesage, M. Barret, N. Bernet, A. Grasmick, J. Hamelin, M. Heran. Water Sci. Technol. 69, 960-965 (2014)

26. D. Ding, C. Feng, Y. Jin, C. Hao, Y. Zhao, Y. Suemura. Desalination. 276, 260-265 (2011)

27. A. Masłoń, JA. Tomaszek. Bioresour. Technol. 196 577-585 (2015)

28. S. Kim, W. Bae, M. Kim, JO. Kim, J. Chung. Environ. Technol. 36, 1035-1043 (2015)

29. F. Liu, S. Zhang, Y. Wang, Y. Li, R. Xiao, H. Li, Y. He, M. Zhang, D. Wang, X. Li, J. Wu. J. Environ. Manage. 166, 596-604 (2016)

30. X. Li, M. Zhang, F. Liu, L. Chen, Y. Li, Y. Li, R. Xiao, J. Wu. Bioresour. Technol. 248, 89-97 (2018) 
31. C. Nicolella, Mc. Van Loosdrecht, JJ. Heijnen. Biotechnol. 80, 1-33 (2000)
32. Z. Ge, D. Wei, J. Zhang, J. Hu, Z. Liu, R. Li. Water Res. 148: 153-161 (2019) 